\title{
FAKTOR-FAKTOR YANG MEMPENGARUHI PEMBIAYAAN USAHA MIKRO KECIL DAN MENENGAH PADA BANK PEMBIAYAAN RAKYAT SYARIAH DI INDONESIA ${ }^{1}$
}

\author{
Fany Arista Wati \\ Departemen Ekonomi Syariah-Fakultas Ekonomi dan Bisnis-Universitas Airlangga \\ Email: faristawati@gmail.com \\ Dian Filianti \\ Departemen Ekonomi Syariah-Fakultas Ekonomi dan Bisnis-Universitas Airlangga \\ Email: dian.filianti@gmail.com
}

\begin{abstract}
ABTRACT:
The purpose of this study was to analyze the effect of Non-Performing Financing, Inflation and the BI rate on Financing Micro, Small and Medium Enterprises (MSMEs) in the Sharia People's Financing Bank in the period January 2013 to October 2018. This study used a quantitative approach. The data used is secondary data from the official website of the Financial Services Authority. The analytical method used in this research is multiple regression analysis (Muliple Linear Regression Analysis) with a significance level of 0.05 . The results show that the Non Performing Financing and Inflation variables partially have a significant effect on MSME financing. While the BI rate variable does not have a significant effect on MSME financing. The results show that the Non Performing Financing, Inflation and Bl rate variables simultaneously have a significant effect on MSME Financing.
\end{abstract}

Keywords: Financing MSME, Non Performing Financing (NPF), Inflation, BI rate

\section{PENDAHULUAN}

Indonesia telah dihadapkan oleh Masyarakat Ekonomi Asean (MEA) yaitu perdagangan bebas antar negara ASEAN. Salah satu dampak yang diberikan dari ekonomi pasar bebas pada masyarakat Indonesia yaitu masyarakat yaitu masyarakat beralih profesi sebagai wirausaha atau biasa disebut sebagai usaha kecil dan menengah (UKM). Faktanya Usaha Kecil dan Menengah mempunyai andil besar dalam memajukan perekonomian. Sektor UKM telah memberikan kontribusi sebesar $60 \%$ terhadap PDB di Indonesia. Sektor UKM juga mempunyai keistimewaan terlihat pada saat terjadi krisis ekonomi pada tahun 1997-1998 yang melemahkan hampir semua sektor ekonomi. Sektor
UMKM mampu bertahan menghadapi goncangan krisis ekonomi yang terjadi. Akan tetapi Sektor UKM menghadapi beberapa permasalahan terutama pada modal. Dimana bagi pelaku usaha kecil aspek permodalan merupakan sangat penting.

Bank mempunyai fungsi sebagai lembaga intermediasi keuangan (financial intermediary institution) yaitu lembaga yang menghimpun dana dari masyarakat dalam bentuk simpanan dan menyalurkan kembali kepada masyarakat dalam bentuk kredit atau pembiayaan. Sebagaimana dijelaskan secara tersirat pada Al-Qur'an Surat Al-Hasyr Ayat 7.

Maksud ayat tersebut menjelaskan agar harta itu tidak hanya berputar pada lingkungan tertentu dari orang-orang kaya

\footnotetext{
${ }^{1}$ Jurnal ini adalah bagian dari skripsi Fany Arista Wati, NIM: 041211431037, yang diuji pada tanggal 16 April 2019.
} 
Wati, et al/Jurnal Ekonomi Syariah Teori dan Terapan Vol. 6 No. 4 April 2019: 846-860; FAKTOR-FAKTOR YANG MEMPENGARUHI PEMBIAYAAN USAHA MIKRO KECIL DAN MENENGAH PADA BANK PEMBIAYAAN RAKYAT SYARIAH DI INDONESIA

(kelebihan dana), akan tetapi tersebar di berbagai pihak sehingga manfaatnya dapat dirasakan oleh orang banyak, dan harta (dana) dapat di distribusikan secara merata. Dalam artian bank dapat menjadi perantara atau tempat untuk orang-orang kaya (kelebihan dana) menginvestasikan dana dan dapat disalurkan kepada orang-oramg yang membutuhkan pinjaman dana. Bank pembiayaan rakyat syariah adalah perbankan yang unik, dimana bank ini beroperasi dalam skala kecil dan diperuntukkan untuk melayani usaha kecil dan menengah.

Berdirinya BPR Syariah mempunyai fokus untuk melayani usaha kecil dan menengah (UKM). Sehingga fokus utamanya inilah yang menjadikan pembeda antara Bank Umum Syariah dengan Bank Pembiayaan Rakyat Syariah. BPRS bersifat aktif dalam memberikan fasilitas pembiayaan kepada usaha-usaha yang berskala kecil dan menengah.

\section{Tabel 1.}

Pembiayaan - Bank Pembiayaan Rakyat Syariah berdasarkan Golongan Pembiayaan dari periode Januari 2013Oktober 2018

\begin{tabular}{|c|c|c|c|c|c|l|}
\hline Pe & 201 & 201 & 201 & 201 & 201 & 201 \\
aya & 3 & 4 & 5 & 6 & 7 & 8 \\
an & & & & & & \\
\hline & 2.62 & 3.00 & 3.37 & 3.57 & 3.76 & 4.15 \\
UK & 0.26 & 5.85 & 7.98 & 0.60 & 7.87 & 3.21 \\
$\mathrm{M}$ & 3 & 8 & 7 & 6 & 7 & 2 \\
\hline $\mathrm{No}$ & 1.81 & 1.99 & 2.38 & 3.09 & 3.99 & 4.63 \\
$\mathrm{n}$ & 3.23 & 9.05 & 7.18 & 1.95 & $\mathbf{6 . 0 7}$ & 7.81 \\
$\mathrm{UK}$ & 0 & 1 & 4 & 0 & 4 & 6 \\
$\mathrm{M}$ & & & & & & \\
\hline T.Pe & $\mathbf{4 . 4 3}$ & $\mathbf{5 . 0 0}$ & $\mathbf{5 . 7 6}$ & $\mathbf{6 . 6 6}$ & $\mathbf{7 . 7 6}$ & $\mathbf{8 . 7 9}$ \\
\hline
\end{tabular}

\begin{tabular}{|c|c|c|c|c|c|l|}
\hline $\begin{array}{c}\text { mbi } \\
\text { aya } \\
\text { an }\end{array}$ & 2.49 & 4.90 & 5.17 & 2.55 & 3.95 & 1.02 \\
1 & 6 & 1 & 8 \\
\hline
\end{tabular}

Sumber: Otoritas Jasa Keuangan, Statistik Perbankan Syariah di Indonesia Periode Januari 2013- Oktober 2018 (www.ojk.go.id).

Seperti yang dijelaskan pada tabel 1 bahwa Bank Pembiayaan Rakyat Syariah mempunyai fokus pembiayaan pada sektor usaha kecil dan menengah di Indonesia dengan jumlah pembiayaan yang sangat besar. Pembiayaan yang diberikan oleh BPRS dari tahun ke tahun terus mengalami peningkatan. Akan tetapi, rasio pembiayaan yang diberikan kepada sektor UMKM mengalami penurunan. Hal ini dapat dilihat pada gambar 1:

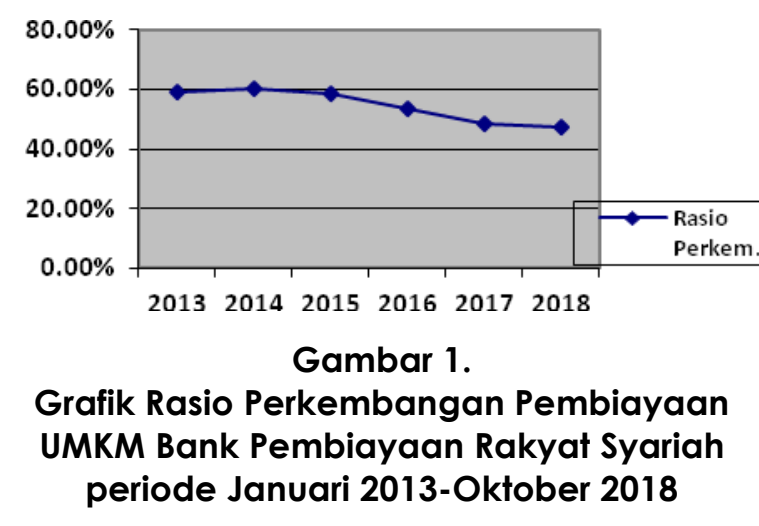

Sumber: Otoritas Jasa Kevangan, Statistik Perbankan Syariah periode Januari 2013Oktober 2017 (data diolah)

Dapat disimpulkan bahwa pembiayaan UMKM yang disalurkan kepada sektor UMKM mengalami kenaikan akan tetapi presentase nya mengalami penurunan. faktor yang mempengaruhi usaha bank untuk menyalurkan dana dalam bentuk 
Wati, et al/Jurnal Ekonomi Syariah Teori dan Terapan Vol. 6 No. 4 April 2019: 846-860; FAKTOR-FAKTOR YANG MEMPENGARUHI PEMBIAYAAN USAHA MIKRO KECIL DAN MENENGAH PADA BANK PEMBIAYAAN RAKYAT SYARIAH DI INDONESIA

pembiayaan. Beberapa diantaranya adalah kondisi internal bank maupun kondisi eksternal bank atau kondisi perekonomian. Salah satu faktor internal bank yang dapat mempengaruhi penyaluran pembiayaan ialah adanya resiko yang dihadapi yaitu terjadinya kredit macet atau pembiayaan bermasalah yang dilakukan oleh nasabah BPRS. Pembiayaan bermasalah ( Non Performing Financing) adalah pinjaman yang mengalami kesulitan pelunasan akibat adanya faktor kesengajaan dan atau karena faktor eksternal diluar kemampuan/kendali nasabah peminjam (Muhammad, 2005:85). Faktor Eksternal yang harus diperhatikan dalam menyalurkan pembiayaan UMKM adalah tingkat suku bunga dan Inflasi. Menurut Sukirno (2004:27) inflasi adalah kenaikan harga-harga umum yang berlaku dalam suatu perekonomian dari suatu periode lainnya. Sehingga mengakibatkan turunnya permintaan masyarakat untuk mendepositokan dananya pada bank dan berdampak pada penyaluran pembiayaan oleh Bank Pembiayaan Rakyat Syariah kepada Usaha Mikro Kecil dan Menengah. BI Rate atau suku bunga Bank Indonesia merupakan suku bunga kebijakan yang mencerminkan sikap atau stance kebijakan moneter yang ditetapkan oleh bank Indonesia dan di umumkan ke publik.

Dari penjelasan diatas penulis akan mengambil judul "Pengaruh Non Performing Financing, Inflasi dan BI Rate terhadap Pembiayaan Usaha Mikro Kecil dan Menegah (UMKM) pada Bank Pembiayaan Rakyat Syariah di Indonesia (Periode Januari 2013- Oktober 2018)".

\section{LANDASAN TEORI}

\section{Usaha Mikro Kecil dan Menengah}

Usaha Mikro adalah usaha produktif milik orang perorangan atau badan usaha perorangan yang memenuhi kriteria. Usaha Kecil adalah usaha ekonomi produktif yang berdiri sendiri, yang dilakukan oleh perorangan atau badan usaha yang bukan merupakan anaka perusahaan atau bukan cabang perusahaan yang dimiliki. Sedangkan Usaha Menengah usaha ekonomi produktif yang berdiri sendiri, yang dilakukan oleh perorangan atau badan usaha yang bukan merupakan anak perusahaan perusahaan yang dimiliki.

\section{Bank Pembiayaan Rakyat Syariah}

Bank Pembiayaan Rakyat Syariah adalah bank yang melaksanakan kegiatan usaha berdasarkan prinsip syariah yang dalam kegiatannya tidak memberikan jasa dalam lalu lintas pembayaran (Ascarya dan Yumanita, 2005:30)

\section{Pembiayaan}

$$
\text { Menurut Rivai (2010:700) }
$$

pembiayaan adalah penyediaan vang atau tagihan yang dapat dipersamakan dengan itu, berdasarkan persetujuan atau kesepakatan pinjam meminjam antara bank atau lembaga keuangan lainnya dengan pihak lain yang mewajibkan 
Wati, et al/Jurnal Ekonomi Syariah Teori dan Terapan Vol. 6 No. 4 April 2019: 846-860; FAKTOR-FAKTOR YANG MEMPENGARUHI PEMBIAYAAN USAHA MIKRO KECIL DAN MENENGAH PADA BANK PEMBIAYAAN RAKYAT SYARIAH DI INDONESIA

pihak peminjam untuk melunasi utangnya setelah jangka waktu tertentu dengan imbalan bagi hasil.

Produk-produk pembiayaan pada BPRS adalah :

1. Pembiayaan Murabahah adalah perjanjian jual beli antara bank dan nasabah dimana bank Islam memebli barang yang diperlukan oleh nasabah dan kemudian menjualnya kepada nasabah yang bersangkutan sebesar harga perolehan ditambah dengan margin yang telah disepakati.

2. Pembiayaan Salam adalah transaksi jual beli dimana barang yang diperjual belikan belum ada.

3. Pembiayaan Istishna adalah perjanjian jual beli dalam bentuk pemesanan pembuatan barang dengan kriteria dan persyaratan tertentu yang disepakati antara pembeli dan penjual.

4. Pembiayaan Mudharabah adalah perjanjianantara penanam dana dan pengelola dana untukmelakukan keiatan usaha tertentu dengan pembagian keuntungan antara kedua belah pihak berdasarkan nisbah yang telah disepakati.

5. Pembiayaan Musyarakah adalah akad kerja sama antara dua pihak atau lebih untuk suatu usaha tertentu dimana masing-masing pihak memeberikan kontribusi dana dengan kesepakatan bahwa keuntungan dan risiko akan ditanggung bersama.

6. ljarah adalah perjanjian sewa menyewa suatu barang dalam waktu tertentu melalui pembayaran sewa.

7. Ijarah Muntahiyah Biltamlik adalah perpaduan antara kontrak jual beli dan sewa atau lebih tepatnya akad sewa yang diakhiri dengan kepemilikan barang di tangan si penyewa.

\section{Non Performing Financing (NPF)}

Non Performing Financing (NPF) merupakan rasio yang mengukur tingkat permasalahan pembiayaan yang dihadapi oleh Bank Syariah.Semakin tinggi rasio ini, menunjukkan kualitas pembiayaan Bank Syariah yang semakin buruk.Semakin tinggi NPF, maka semakin tinggi debitur yang tidak memberikan kewajibannya dalam bentuk margin ataupun bagi hasil kepada kreditur, sehingga berpotensi menurunkan pendapatan bank serta menurunkan Aset sehingga pertumbuhan aset menurun (Ihsan, 2013:96).

Non Perforiming Financing (NPF) merupakan sumber kerugian yang sangat potensial bagi bank jika tdak ditangani dengan baik, karena diperlukan penanganan yang sistematis dan berkelanjutan.NPF menimbulkan biaya yang menjadi beban dan kerugian pada bank.

\section{Penyebab Non Performing Financing (NPF)}

Menurut Ismail (2010:123) faktor faktor penyebab terjadinya Non Performing Financing (NPF), yaitu:

1. Faktor Intern Bank

a. Analisis kurang tepat, sehingga tidak dapat memprediksi apa yangakan terjadi dalam kuru waktu selam 
jangka waktu kredit. Misalnya, kredit diberikan tidak sesuai dengan kebutuhan, sehingga nasabah tidak mampu membayar angsuran yang melebihi kemampuan.

b. Adanya kolusi antara pejabat bank yang menangani kredit dan nasabah, sehingg bank memutuskan kredit yang tidak seharusnya diberikan. Misalnya, bank melakukan over taksasi terhadap nilai agunan.

c. Keterbatasan pengetahuan pejabat bank terhadap jenis usaha debitur, sehingga tidak dapat melakukan analisis dengan tepat dan akurat.

d. Campur tangan terlalu besar dari pihak terkait, misalnya komisaris, direktur bank sehingga petugas tidak independen dalam meutuskan kredit.

e. Kelemahan dalam melakukan pembinaan dan monitoring kredit debitur.

\section{Faktor Ekstern Bank}

a. Unsur kesengajaan yang dilakukan oleh nasabah.

1) Nasabah sengaja untuk tidak melakukan pembayaran angsuran kepada bank, karena nasabah tidak memiliki kemauan dalam memenuhi kewajibannya.

2) Debitur melakukan ekspansi terlalu besar, sehingga dana yang dibutuhkan terlalu besar. Hal ini akan memiliki dampak terhadap keuangan perusahaan dalam memnuhi kebutuhan modal kerja.

3) Penyelewengan yang dilakukan nasabah dengan menggunakan dana kredit tersebut tidak sesuai dengan tujuan penggunaan (side streaming). Misalnya, dalam pengajuan kredit disebutkan kredit untuk investasi, ternyata dalam prakteknya setelah dana dicairkan digunakan untuk modal kerja.

b. Unsur ketidaksengajaan

1) Debitur mau melaksanakan kewajiban sesuai perjanjian, akan tetapi kemampuan perusahaan sangat terbatas, sehingga tidak dapat membayar angsuran.

2) Perusahaannya tidak dapat bersaing dengan pasar, sehingga volume penjualan menurun dan perusahaan merasa rugi.

3) Perubahan kebijakan dan peraturan pemerintah yang berdampak pada usaha debitur

4) Bencana alam yang dapat menyebabkan kerugian debitur.

NPL/NPF Kredit atau Pembiayaan UMKM adalah penjumlahan Kredit atau Pembiayaan dengan kualitas kuarang lancar, diragukan, dan macet yang disalurkan Bank Umum kepada pelaku usaha yang memenuhi kriteria UMKM. Perhitungan rasio NPL/NPF Kredit atau Pembiayaan UMKM dilakukan dengan membandingkan NPL/NPF Kredit atau Pembiayaan UMKM terhadap total Kredit 
Wati, et al/Jurnal Ekonomi Syariah Teori dan Terapan Vol. 6 No. 4 April 2019: 846-860; FAKTOR-FAKTOR YANG MEMPENGARUHI PEMBIAYAAN USAHA MIKRO KECIL DAN MENENGAH PADA BANK PEMBIAYAAN RAKYAT SYARIAH DI INDONESIA

atau Pembiayaan UMKM Bank Umum.

Inflasi

Boediono (1995:155) Inflasi adalah kecenderungan dari harga-harga untuk menaik secara umum dan terus menerus. Kenaikan harga dari satu atau dua barang saja tidak disebut inflasi, kecuali bila kenaikan tersebut meluas kepada (atau mengakibatkan kenaikan) sebagian besar dari harga barang-barang lain.

\section{BI rate}

Suku bunga secara singkat adalah harga dari penggunaan vang untuk jangka waktu tertentu (Boediono, 1995:75). Suku bunga mempengaruhi keputusan individu terhadap pilihan membelanjakan uang lebih banyak atau menyimpan vangnya dalam bentuk tabungan. Tingkat bunga adalah bunga per tahun sebagai presentase dari jumlah yang dipinjamkan.

\section{METODE PENELITIAN}

\section{Pendekatan Penelitian}

Jenis pendekatan yang digunakan dalam penelitian ini adalahpendekatan bersifat kuantitatif.

\section{Identifikasi Variabel}

Variabel Eksogen: Non Performing Financing (NPF) (X1), Inflasi (X2), BI rate (X3).

Variabel Endogen : Pembiayaan UMKM (Y).

\section{Definisi Operasional Variabel}

a. Non Performing Financing (NPF) (X1)

Menurut Statistik Perbankan Syariah (SPS), Non Performing Financing (NPF) merupakan rasio pembiayaan terhadap total pembiayaan. Menurut Ihsan rasio NPF diperoleh dengan rumus sebagai berikut:

NPFs $\frac{\text { Pembiayaan Bermasalah UNKM x10076 }}{\text { Total Pembaiyaan UMKM }}$

b. Inflasi (X2)

Inflasi adalah kenaikan harga barang-barang yang bersifat umum dan secara terus menerus dalam jangka waktu yang relatif panjang. Data yang diambil langsung dari website Bank Indonesia yang dinyatakan dalam satuan persen.

c. Bl rate $(\mathrm{X} 3)$

$\mathrm{Bl}$ rate merupakan suku bunga kebijakan yang mencerminkan sikap atau stance kebijakan moneter yang ditetapkan oleh Bank Indonesia dan diumumkan kepada publik. Data BI rate ini diperoleh dari situs resmi Badan Pusat Statistik periode Januari 2013 sampai Oktober 2018.

d. Pembiayaan UMKM (Y)

Pembiayaan Usaha Mikro Kecil dan Menengah merupakan penyaluran dana oleh bank syariah dengan prinsip bagi hasil (syirkah ) yang terdiri dari pembiayaan dalam bentuk akad mudharabah dan musyarakah, prinsip jual beli (ba'i), pembiayaan dengan prinsip sewa beli (ijarah mutahiyyah bittamlik), dan prinsip Qard. Data yang digunakan adalah jumlah pembiayaan Usaha Kecil dan Menengah yang disalurkan oleh bank pembiayaan rakyat syariah di Indonesia yang diambil langsung dari laporan kevangan yang dinyatakan dalam satuan jutaan rupiah.

\section{Jenis dan Sumber Data}

Jenis data yang digunakan dalam 
Wati, et al/Jurnal Ekonomi Syariah Teori dan Terapan Vol. 6 No. 4 April 2019: 846-860; FAKTOR-FAKTOR YANG MEMPENGARUHI PEMBIAYAAN USAHA MIKRO KECIL DAN MENENGAH PADA BANK PEMBIAYAAN RAKYAT SYARIAH DI INDONESIA

penelitian ini adalah data sekunder. Datadata yang diambil adalah data dari publikasi laporan keuangan bank pembiayaan rakyat syariah yaitu pembiayaan Usaha Kecil dan Menengah, Non Performing Financing sedangkan data Inflasi publikasi Bank Indonesia dan BI rate diambil dari publikasi Badan Pusat Statistik.

Periode yang diambil dalam penelitian ini adalah bulan Januari 2013 sampai dengan Oktober 2018. Sumber data pada penelitian ini diperoleh dari laporan Statistik Perbankan Syariah (SPS) dengan mengakses website resmi Otoritas Jasa Keuangan, mengakses website resmi Bank Indonesia dan mengakses website Badan Pusat Statistik.

\section{Populasi dan Sampel}

Populasi adalah wilayah generalisasi yan terdiri atas subyek yang mempunyai kualitas dan karakteristik tertentu yang ditetapkan oleh peneliti untuk dipelajari dan kemudian ditarik kesimpulannya (Anshori dan Iswati, 2009:92). Populasi yang digunakan dalam penelitian ini adalah seluruh bank pembiayaan rakyat syariah di Indonesia periode Januari 2013-Oktober 2018.

Sampel adalah bagian yang menjadi obyek yang sesungguhnya dari penelitian tersebut. Metode pemilihan sampel yang digunakan dalam penelitian ini adalah metode pemilihan sampel non acak (non probability sampling). Non probability sampling adalah teknik pengambilan sampel yang tidak memberi peluang atau kesempatan sama bagi setiap unsur atau anggota populasi untuk dipilih menjadi sampel (Anshori dan Iswati, 2009:105).

\section{Prosedur Pengumpulan Data}

Prosedur pengumpulan data yang digunakan dalam penelitian ini adalah sebagai berikut :1) Studi Kepustakaan, yaitu mengumpulkan teori-teori pendukung dari literature dan penelitianpenelitian terdahulu tentang gambaran masalah yang diteliti. 2) Pengumpulan data-data sekunder yang diperlukan, yaitu data statistik perbankan syariah dan Bank Indonesia dari periode Januari 2013 sampai dengan Oktober 2018 yang diakses dari website resmi Otoritas Jasa Keuangan (ojk.go.id), Badan Pusat Statistik (www.bps.go.id) dan Bank Indonesia (www.bi.go.id).

\section{Teknik Analisis}

Untuk dapat menjawab hipotesis teknik analisis data yang digunakan dalam penelitian ini adalah analisis regresi berganda (Muliple Linier Regression Analysis). Model linier berganda digunakan untuk mengetahui pengaruh hubungan antara variabel independen dan dependen dimana independen lebih dari satu variabel (Saroko, 2005:45).

\section{Analisis Regresi Linier Berganda}

Analsis regresi linier berganda (linier multiple regression) adalah analisis yang berkenaan dengan studi keterikatan satu variabel terikat (dependent variable) terhadap beberapa variabel bebas (independent variable) yang jumlahnya 
Wati, et al/Jurnal Ekonomi Syariah Teori dan Terapan Vol. 6 No. 4 April 2019: 846-860; FAKTOR-FAKTOR YANG MEMPENGARUHI PEMBIAYAAN USAHA MIKRO KECIL DAN MENENGAH PADA BANK PEMBIAYAAN RAKYAT SYARIAH DI INDONESIA

lebih dari satu. Regresi dilakukan untuk mengetahui sejauh mana variabel bebas mempengaruhi variabel terikat. Pada regresi berganda terdapat satu variabel terikat dan lebih dari satu variabel bebas.

Dalam penelitian ini yang menjadi variabel terikat adalah Pembiayaan UMKM sedangkan yang menjadi variabel bebas adalah Non Performing financing, Inflasi BI rate, Adapun model hubungan variabel-variabel tersebut disusun dalam fungsi atau persamaan sebagai berikut:

$Y=a+\beta 1 X 1+\beta 2 X 2+\beta 3 X 3+e$

$\mathrm{Y}=$ Pembiayaan UMKM

a $=$ Konstanta dari persamaan regresi

ß1-3 = Koefisien regresi dari variabel independen

$\mathrm{X} 1-3=$ Variabel independen

IV. HASIL DAN PEMBAHASAN

\section{Deskripsi Hasil Penelitian}

Penelitian ini bertujuan untuk mengetahui pengaruh Non Performing Financing, Inflasi dan BI rate terhadap pembiayaan UMKM pada Bank Pembiayaan Rakyat Syariah di Indonesia. Data tersebut kemudian diolah dengan menggunakan metode regresi linier berganda serta menggunakan perangkat lunak SPSS untuk memperolehh hasil penelitian. Untuk mengetahui deskripsi data dapat dilihat pada Tabel berikut :

\section{Tabel 2.}

Deskripsi Variabel Penelitian Oktober 2014 sampai April 2018

\begin{tabular}{|l|l|l|l|}
\hline Var & Mini & Max & Mean \\
\hline
\end{tabular}


Wati, et al/Jurnal Ekonomi Syariah Teori dan Terapan Vol. 6 No. 4 April 2019: 846-860; FAKTOR-FAKTOR YANG MEMPENGARUHI PEMBIAYAAN USAHA MIKRO KECIL DAN MENENGAH PADA BANK PEMBIAYAAN RAKYAT SYARIAH DI INDONESIA

normalitas.

\section{Uji Multikolinearitas}

Hasil pengujian multikolinearitas dalam penelitian ini ditunjukkan dalam tabel berikut ini:

Tabel 3.

Uji Multikolinearitas

\begin{tabular}{|l|c|c|}
\hline $\begin{array}{c}\text { Variabel } \\
\text { Bebas }\end{array}$ & $\begin{array}{c}\text { Nilai } \\
\text { VIF }\end{array}$ & $\begin{array}{c}\text { Nilai } \\
\text { Tolerance }\end{array}$ \\
\hline X1 & 1,553 & 0,644 \\
\hline X2 & 2,337 & 0,428 \\
\hline X3 & 2,094 & 0,477 \\
\hline
\end{tabular}

Sumber : data olah SPSS pada lampiran

Berdasarkan tabel 4.3 diketahui bahwa semua variabel bebas yaitu NPF $\left(X_{1}\right)$, Inflasi $\left(X_{2}\right), B$ rate $\left(X_{3}\right)$, mempunyai nilai VIF $\leq 10$. dan nilai Tolerance $\geq 0.1 \mathrm{Hal}$ ini dapat disimpulkan bahwa pada model regresi tidak terjadi Multikolinearitas.

\section{Uji Autokorelasi}

Uji autokorelasi adalah untuk mengetahui apakah dalam model regresi linier ada korelasi antara kesalhan pengganggu pada periode $t$ dengan kesalahan pada periode $t-1$. Perhitungannya adalah menggunakan metode Durbin-Watson. Jika nilai DW terletak diantara -2 hingga +2 tidak autokorelasi. Berikut hasil uji autokorelasi durbin watson:

Tabel 4.

Uji Autokorelasi

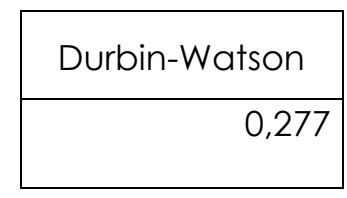

Sumber: Hasil Pengolahan Data Lampiran Dengan demikian tidak terdapat masalah autokorelasi pada data yang digunakan dalam penelitian.

\section{Uji Heteroskedastisitas}

uji heteroskedastisitas adalah untuk menguji apakah dalam model regresi terjadi ketidaksamaan varian dari residual satu pengamatan ke pengamatan lain. (Widarjo, 2010:84). Cara mendeteksi ada atau tidaknya heteroskedastisitas dapat dilakukan dengan cara melihat pola tertentu pada grafik Scatterplot.Berikut merupakan hasil uji heteroskedastisitas:

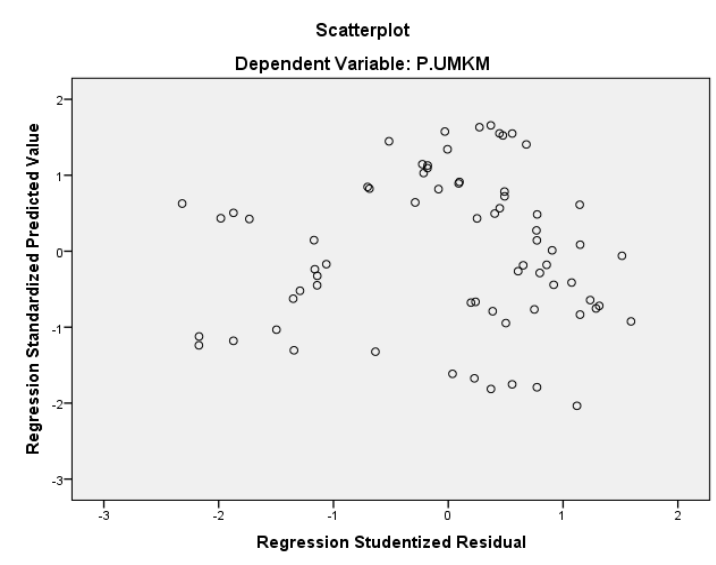

Gambar 3.

Uji Heteroskedastisitas

Sumber: data diolah SPSS pada Lampiran Berdasarkan gambar diatas bahwa titik-titik yang terbentuk telah menyebar secara acak dan tersebar baik di atas maupun di bawah angka 0 pada sumbu Y. Maka disimpulkan bahwa tidak mengalami heteroskedastisitas.

\section{Pembuktian Hipotesis}

\section{Uji Statistik † (Parsial)}

Uji † dipakai untuk melihat signifikansi dari perngaruh variabel independen secara individu terhadap dependen. Variabel independen dapat dikatakan 
Wati, et al/Jurnal Ekonomi Syariah Teori dan Terapan Vol. 6 No. 4 April 2019: 846-860; FAKTOR-FAKTOR YANG MEMPENGARUHI PEMBIAYAAN USAHA MIKRO KECIL DAN MENENGAH PADA BANK PEMBIAYAAN RAKYAT SYARIAH DI INDONESIA

mempengaruhi variabel dependen secara parsial dengan syarat jika thitung > tabel dan nilai signifikansi $<0,05$. Hasil Penghitungan uji † dijelaskan dalam tabel berikut:

\section{Tabel 5.}

Uji Statistik †

\begin{tabular}{|l|c|c|c|c|}
\hline Var & Thitung $_{\text {Ttabel }}$ & Sig. & Ket \\
\hline X1 & 7,622 & 1,99714 & 0,000 & S \\
\hline X2 & $-3,237$ & 1,99714 & 0,002 & S \\
\hline X3 & $-0,200$ & 1,99714 & 0,842 & TS \\
\hline
\end{tabular}

Sumber: Hasil Pengolahan Data.Lampiran

Dari tabel diatas 4.7, maka hasil regresi berganda dapat dianalisis sebagai berikut:

1. Non Performing Financing

Variabel Non Performing Financing memiliki thitung sebesar 7,622 dengan tabel sebesar 1,99714 sehingga thitung lebih besar dari $t_{\text {tabel }}$ dan jika nilai $t_{\text {hitung }}>t_{\text {tabel }}$ maka Ho ditolak $\mathrm{H}_{1}$ diterima, selain itu dikuatkan oleh nilai signifikansi sebesar 0,000 sehingga kesimpulannya Non Performing Financing secara parsial berpengaruh signifikan terhadap Pembiayaan UMKM.

2. Inflasi

Variabel Inflasi memiliki thitung sebesar -3,237 dengan tabel sebesar 1,99714 sehingga thitung lebih besar dari $t_{\text {tabel }}$ dan jika nilai $t_{\text {hitung }}>t_{\text {tabel }}$ maka Ho ditolak $\mathrm{H}_{1}$ diterima, dan nilai signifikansi sebesar 0,002 sehingga kesimpulannya Inflasi secara parsial berpengaruh signifikan terhadap Pembiayaan UMKM.

3. Bl rate

Variabel $\mathrm{BI}$ rate memiliki thitung sebesar -0,200 dengan tabel sebesar
1,99714 sehingga thitung lebih kecil dari tabel dan jika nilai thitung $<t_{\text {tabel }}$ maka Ho diterima dan $\mathrm{H}_{1}$ ditolak, dan signifikansi sebesar 0,842 sehingga kesimpulannya $\mathrm{BI}$ rate secara parsial tidak berpengaruh signifikan terhadap Pembiayaan UMKM.

\section{Uji Statistik F (Simultan)}

Uji $F$ dilakukan untuk mengetahui semua variabel independen secara simultan berpengaruh terhadap variabel dependen dengan membandingkan $F$ tabel

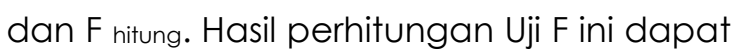
dilihat pada tabel berikut ini:

Tabel 6.

Uji Statistik F

\begin{tabular}{|c|c|c|c|}
\hline Fhitung & Ftabel & Sig. & Ket \\
\hline 58,071 & 2,51 & 0,000 & S \\
\hline
\end{tabular}

Sumber: Hasil Pengolahan Data Lampiran

Dari hasil analisis regresi dapat diketahui bahwa secara bersama-sama variabel independen meiliki pengaruh yang signifikan terhadap variabel dependen. Hal ini dapat dibuktikan dari nilai $F$ hitung sebesar 58,071 lebih besar $F_{\text {tabel }}$ dengan nilai signifikansi 0,000. Maka dapat dinyatakan bahwa $\mathrm{Ho}$ ditolak dan $\mathrm{H}_{1}$ diterima maka dapat disimpulkan bahwa secara simultan variabel Non Performing Financing, Inflasi dan Bl rate berpengaruh signifikan terhadap Pembiayaan UMKM.

\section{Analisis Koefisien Determinasi ( $\left.\mathbf{R}^{2}\right)$}

Untuk mengukur sebrapa jauh kemampuan variabel independen dalam menjelaskan variabel dependen.

Tabel 7.

Koefisien Determinasi $\left(\mathbf{R}^{2}\right)$ 
Wati, et al/Jurnal Ekonomi Syariah Teori dan Terapan Vol. 6 No. 4 April 2019: 846-860; FAKTOR-FAKTOR YANG MEMPENGARUHI PEMBIAYAAN USAHA MIKRO KECIL DAN MENENGAH PADA BANK PEMBIAYAAN RAKYAT SYARIAH DI INDONESIA

\begin{tabular}{|c|c|c|}
\hline$R$ & R Square & $\begin{array}{c}\text { Adjusted } R \\
\text { Square }\end{array}$ \\
\hline 0,852 & 0,725 & 0,713 \\
\hline
\end{tabular}

Sumber : data olah SPSS pada lampiran

Dapat dilihat pada tabel 4.8 menunjukkan Koefisien Determinasti $\left(R^{2}\right)$ sebesar 0,725 atau sebesar $72,5 \%$ hal ini berarti bahwa Non Performing Financing, Inflasi dan Bl Rate dapat menjelaskan variabel Pembiayaan Usaha Mikro Kecil dan Menengah adalah sebesar 72,5\% atau sebesar $72,5 \%$ sedangkan sisanya sebesar atau 27,5\% dipengaruhi oleh variabel lain diluar variabel bebas yang digunakan dalam penelitian.

\section{Pembahasan}

\section{Pengaruh NPF terhadap Pembiayaan UMKM}

Hasil pengujian tentang pengaruh NPF terhadap pembiayaan UMKM menunjukkan bahwa rasio NPF berpengaruh signifikan terhadap pembiayaan UMKM. Oleh karena itu, hipotesis pertama $\left(\mathrm{H}_{1}\right)$ yang menyatakan bahwa NPF berpengaruh signifikan terhadap pembiayaan UMKM pada Bank Pembiayaan Rakyat Syariah diterima.

Hasil pengujian pada variabel ini Menurut Wangswidjaja (2012:91), Non Performing Financing terjadi saat nasabah tidak atau belum mampu untuk membayar kembali pokok pembiayaan dan atau membayar imbalan atau bagi hasil sebagaimana yang telah disepakati. Hasil penelitian ini didukung oleh pendapat Nurdin (2017) dan Purwidianti (2014) bahwa Non Performing Financing berpengaruh terhadap pembiayaan Usaha Mikro Kecil dan Menengah. Karena apabila suatu bank memiliki rasio Non Performing Financing yang tinggi maka untuk menutupi presentase Non Performing Financing tersebut, maka BPRS akan menambah jumlah alokasi pembiayaan yang akan disalurkan.

\section{Pengaruh Inflasi terhadap Pembiayaan UMKM}

Hasil pengujian tentang pengaruh Inflasi terhadap pembiayaan Bank Pembiayaan Rakyat Syariah menunjukkan bahwa rasio Inflasi berpengaruh signifikan terhadap pembiayaan UMKM. Oleh karena itu, hipotesis pertama $\left(H_{1}\right)$ yang menyatakan bahwa NPF berpengaruh signifikan terhadap pembiayaan UMKM pada Bank Pembiayaan Rakyat Syariah diterima.

Hasil dari pengujian bahwa inflasi dapat mempengaruhi besar kecilnya pembiayaan Usaha Mikro Kecil dan Menengah pada Bank Pembiayaan Rakyat Syariah. Hal ini sesuai dengan pendapat yang dikemukakan oleh Putong (2003:54) bahwa terjadinya inflasi menyebabkan menurunnya daya beli vang masyarakat secara umum, karena saat inflasi meningkat pendapatan riil masyarakat akan mengalami penurunan. Fluktuasi laju inflasi menunjukkan ketidakstabilan pada harga-harga sehingga masyarakat lebih senang memegang uangnya dalam bentuk kas daripada menginvestasikan dananya pada perbankan. Sehingga akan 
Wati, et al/Jurnal Ekonomi Syariah Teori dan Terapan Vol. 6 No. 4 April 2019: 846-860; FAKTOR-FAKTOR YANG MEMPENGARUHI PEMBIAYAAN USAHA MIKRO KECIL DAN MENENGAH PADA BANK PEMBIAYAAN RAKYAT SYARIAH DI INDONESIA

mengakibatkan berkurangnya dana yang masuk pada perbankan sehingga penyaluran pembiayaan pada perbankan juga ikut berkurang.

Hasil penelitian ini didukung oleh Daud (2016) bahwa Inflasi berpengaruh signifikan terhadap pembiayaan UMKM. Inflasi yang tinggi dan tidak terkendali dapat mengganggu upaya perbankan dalam pengerahan dana masyarakat. Hal ini juga didukung dengan hasil penelitian oleh Nurdin (2017) dan Purwidianti \& Hidayah (2014) bahwa jika tingkat inflasi tinggi maka masyarakat akan lebih condong membelanjakan vangnya pada hal non-produktif sehingga mengakibatkan menurunya permintaan masyarakat untuk menabungkan dananya pada bank, yang berarti juga akan mempengaruhi penyaluran dana pembiayaan oleh perbankan kepada Usaha Mikro Kecil dan Menengah (UMKM). Akan tetapi hasil penelitian ini juga bertolak belakang dengan penelitian yang dilakukan oleh Shinta (201) dan Dahlan (2015) yang menyimpulkan bahwa inflasi tidak berpengaruh signifikan terhadap pembiayaan UMKM. Menurut analisisnya bahwa dari sisi permintaan meskipun terjadi inflasi baik naik atau turun UMKM akan tetap membutuhkan modal untuk menjalankan usahanya.

\section{Pengaruh $\mathrm{BI}$ rate terhadap Pembiayaan UMKM}

Hasil pengujian tentang pengaruh BI rate terhadap pembiayaan UMKM Bank Pembiayaan Rakyat Syariah menunjukkan bahwa BI rate tidak berpengaruh signifikan terhadap pembiayaan UMKM.

Hasil pengujian pada variabel ini BI rate merupakan tingkat suku bunga yang ditetapkan oleh Bank Indonesia dan menjadi penuntun atas penetapan suku bunga kredit dan suku bunga komersial lainnya. Bl rate tersebut juga dipresentasikan dalam bentuk Sertifikat Bank Indonesia (SBI) dan Sertifikat Bank Indonesia Syariah (SBIS) yang merupakan salah satu instrumen investasi yang dijamin oleh pemerintah langsung. Dalam hal ini Bank Indonesia sendirilah yang menjadi penjaminnya, sehingga penetapan $\mathrm{BI}$ rate juga akan berdampak pada keputusan pemilihan investasi oleh para investor (Kasmir, 2008:241). BI rate dalam penelitian ini tidak berpengaruh signifikan terhadap pembiayaan UMKM. Hasil penelitian ini didukung oleh Daud (2016) yang menyimpulkan bahwa $\mathrm{Bl}$ rate tidak berpengaruh terhadap pembiayaan UMKM. Bahwa semakin tinggi suku bunga $\mathrm{SBI}$ akan mendorong jumlah kredit yang disalurkan namun dalam tingkat yang tidak signifikan meskipun pada periode penelitian suku bunga SBI masih tetap tinggi tetapi permintaan kredit masih ada. Karena pada perbankan syariah menggunakan sistem bagi hasil dalam kegiatan operasionalnya, maka juga tetap memperhatikan sistem perekonomian di Indonesia. Hal ini juga sependapat dengan penelitian Syaichu dan Wibowo (2013) bahwa suku bunga tidak berpengaruh signifikan terhadap 
Wati, et al/Jurnal Ekonomi Syariah Teori dan Terapan Vol. 6 No. 4 April 2019: 846-860; FAKTOR-FAKTOR YANG MEMPENGARUHI PEMBIAYAAN USAHA MIKRO KECIL DAN MENENGAH PADA BANK PEMBIAYAAN RAKYAT SYARIAH DI INDONESIA

ROA. Hal ini disebabkan pertama, nasabah bank syariah nampaknya merupakan nasabah yang relatif loyal terhadap bank syariah. Dalam hal ini adalah nasabah yang cenderung mengutamakan pada prinsip-prinsip syariah sedikit kecil menerapkan prinsip untuk mendapatkan bunga yang dinilai sebagai riba.

\section{Pengaruh NPF, Inflasi dan BI rate secara} bersama-sama terhadap Pembiayaan UMKM

Hasil pengujian regresi linier berganda menunjukkan bahwa variabel NPF, Inflasi, dan Bl rate secara bersamasama berpengaruh signifikan terhadap Pembiayaan UMKM. Oleh karena itu, dapat dinyatakan bahwa hipotesis kelima (H1) diterima yaitu NPF, Inflasi, dan BI rate secara bersama-sama berpengaruh signifikan terhadap Pembiayaan UMKM. Besarnya pengaruh tersebut adalah sebesar 0,725 atau sebesar 72,5\% sedangkan sisanya sebesar 0,275 atau 27,5 \% dipengaruhi oleh variabel lain diluar penelitian.

\section{v. SIMPULAN}

Berdasarkanpada hasil analisis dan pembahasan pada bab sebelumnya, maka dapat disimpulkan sebagai berikut:

1. Berdasarkan hasil uji signifikan $t$, diperoleh kesimpulan bahwa variabel NPF dan Inflasi secara parsial berpengaruh signifikan terhadap pembiayaan UMKM. Sedangkan variabel $\mathrm{BI}$ rate tidak berpengaruh signifikan terhadap pembiayaan UMKM.

2. Berdasarkan hasil uji F, diperoleh hasil bahwa NPF, Inflasi dan Bl rate secara simultan berpengaruh signifikan terhadap pembiayaan UMKM.

\section{Saran}

Dari hasil penelitian yang telah dilakukan, maka penulis mengajukan saran-saran sebagai berikut:

1. Bagi Manajemen Bank:

a. Agar selalu menjaga kinerjanya sehingga bank selalu berada dalam keadaan yang ideal

b. Meningkatkan kualitas analisis pembiayaan yang berintegrasi dalam menyalurkan pembiayaan sehingga dapat selalu meminimalisir tingkat Non Performing Financing dengan tetap memperhatikan prinsip syariah.

2. Bagi penelitian selanjutnya:

Penambahan periode penelitian untuk menambah jumlah data sehingga dimungkinkan dapat merubah hasil penelitian yang telah di dapatkan.

\section{DAFTAR PUSTAKA}

Anshori, Muslich dan Sri Iswati. 2009. Buku Ajar Metodologi Penelitian Kuantitatif. Surabaya: Airlangga University Press.

Ascarya \& Diana Yumanita. 2005. Bank Syariah: Gambaran Umum. Jakarta: Pusat Pendidikan dan Studi Kebanksentralan (PPSK).

Boediono. 1995. Seri Sinopsis Pengantar 
Wati, et al/Jurnal Ekonomi Syariah Teori dan Terapan Vol. 6 No. 4 April 2019: 846-860; FAKTOR-FAKTOR YANG MEMPENGARUHI PEMBIAYAAN USAHA MIKRO KECIL DAN MENENGAH PADA BANK PEMBIAYAAN RAKYAT SYARIAH DI INDONESIA

Ilmu Ekonomi No. 2 Ekonomi Makro. Yogyakarta: BPPE.

Daud, Annisa Nurhidayati Arief. 2016. Analisis Pengaruh Inflasi, Bl Rate, Sertifikat Bank Syariah (SBIS), Non Performing Financing (NPF) dan Dana Pihak Ketiga (DPK) Terhadap Pembiayaan Usaha Kecil dan Menengah (UKM) pada Perbakan Syariah di Indonesia. Disertasi Tidak diterbitkan. Jakarta Fakultas Ekonomi dan Bisnis UIN Syarif Hidayatullah Jakarta.

Dahlan, Rahmat. 2014. Pengaruh Tingkat Bonus Sertifikat Bank Indonesia Syariah dan Tingkat Inflasi Terhadap Pembiayaan Bank Syariah di Indonesia. Jurnal Etikonomi, Volume. 13 No 2.

Departemen Agama RI. 2008. Alquran dan Terjemahan. CV. Toha Putra. Semarang.

Insan, Dwi Nur'aini. 2013. Analisa Laporan Kevangan Perbankan Syariah. Jakarta: UIN Jakarta Press

Ismail. 2010. Manajemen Perbankan Dari Teori Menuju Aplikasi. Jakarta: Kencana.

Kasmir. 2008. Bank dan Lembaga Keuangan Linnya. Edisi Revisi. Jakarta: Rajawali Pers.

Muhammad. 2005. Manajemen Bank Syariah. Yogyakarta: UPP AMP YKPN.

Nurdin, M.Ainun. 2017. Pengaruuh Non Performing Financing, Dana Pihak Ketiga, Tingkat Suku Bunga dan
Inflasi terhadap Pembiayaan Usaha Mikro Kecil dan Menengah di Bank Pembiayaan Rakyat Syariah di Indonesia. Disertasi tidak diterbitkan. Tulungagung Fakultas Ekonomi dan Bisnis Islam IAIN Tulungagung.

Purwidianti, Wida dan Arini Hidayah. 2014. Faktor-faktor yang Mempengaruhi Alokasi Pembiayaan Perbankan Syariah untuk Usaha Mikro Kecil dan Menengah di Indonesia. Prosiding Seminar Hasil Penelitian. LPPM UMP 2014.

Putong, Iskandar. 2003. Pengantar: Ekonomi Mikro dan Makro. Edisi Kedua. Jakarta: Ghalia Indonesia.

Rahmawan, Ayu Shinta. 2017. Pengaruh Faktor Internal dan Eksternal Pembiayaan Bank Umum Syariah untuk Sektor UMKM di Indonesia. Disertasi tidak diterbitkan. Bogor Fakultas Ekonomi dan Manajemen Institut Pertanian Bogor.

Rivai, Veithzal dan Arvivan Arifin. 2010. Islamic Banking:Sebuah Teori, Konsep Dan Aplikasi. Jakarta: PT Bumi Aksana.

Sukirno, Sadono. 2004. Makro Ekonomi Teori Pengantar. Jakarta: PT Raja Grafindo Perkasa.

Surat Edaran Bank Indonesia No. 17/19/DPUM. (http://www.bi.go.id, diunduh pada tanggal 18 Desember 2017).

Widarjono, Agus. 2010. Analisis Statistika Multivariat Terapan. Yogyakarta: 
UPP STIM YKPN.

Mulyono, Pudjo Teguh. 2004. Manajemen

Perkreditan. Yogyakarta: Salemba

Empat.

Otoritas Jasa Keuangan. 2010. Statistik Perbankan Syariah 2014. Dalam www.ojk.go.id

P.Usanti, Trisadini dan Abd Shomad. 2015. Transaksi Bank Syariah. Jakarta: PT Bumi Akasra.

Puspa, Widya Andika, Isti Fadah, Novi Puspitasari. 2015. Analisis pengaruh Non Performing Financing Pembiayaan Murabahah, Mudharabah dan Musyarakah terhadap Profitabilias pada Bank Umum Syariah. Jember: UNEJ.

Republik Indonesia. 1998. Undang undang Nomor 10 Tahun 1998 Tentang Perubahan atas Undang undang Nomor 7 Tahun 1992tentang Perbankan. Skretariat Negara. Jakarta

Sudarsono, Heri. 2008. Bank dan Lembaga Keuangan Syariah Deskripsi dan Ilustrasi. Yogyakarta: EKONISIA

Wahid, Sulaiman. 2004. Analisis-analisis Regresi menggunakan SPSS. Yogyakarta: Andi. 